\title{
MENGGUNAKAN TEKS SEBAGAI SARANA ADAPTASI SOSIAL
}

\author{
THE USE OF TEXT AS A MEANS OF \\ SOCIAL ADAPTATION
}

\author{
Dessy Wahyuni \\ Balai Bahasa Provinsi Riau \\ Kementerian Pendidikan dan Kebudayaan \\ Jalan Binawidya, Kompleks Universitas Riau, Panam, Pekanbaru \\ Pos-el: dessy_wahyuni@yahoo.com \\ Ponsel: 08127689464
}

\begin{abstract}
Communication has been a part of human life. As social beings, people always want to get connected. In other words, communication is fundamental for a person in social life. When communicating, people deliver messages to others. In order for the messages to be delivered, text with which language is the medium is required. Therefore, text has a very important role as a means of social adaptation. In 2013, Agency of Language Development and Fostering launched 2013 curriculum with text-based-learning scheme to bring a new paradigm for education in Indonesia. Textual learning enables children to resolve real-life problems with critical thinking and to engage with social adaptation. In the process of adaptation, individual delivers thoughts, ideas, messages through text with which language is the medium. This study used descriptive method to obtain the description of text use as a means of social adaptation. By examining Indonesia Language Textbook in I, IV, VII, and X grade, it can be concluded that every text has different social function together with different communication purpose among human beings.
\end{abstract}

Keywords: text, textual learning, social adaptation, language, and communication

\begin{abstract}
Abstrak
Komunikasi telah menjadi bagian dari kehidupan manusia. Sebagai makhluk sosial, manusia senantiasa ingin berhubungan dengan manusia lainnya. Dalam hal ini, berkomunikasi merupakan hal yang fundamental bagi seseorang dalam hidup bermasyarakat. Ketika berkomunikasi terdapat pesan yang hendak disampaikan seseorang kepada orang lain, baik secara individu maupun berkelompok. Agar pesan yang akan disampaikan itu bisa mencapai tujuan, diperlukan teks dengan bahasa sebagai medianya. Oleh sebab itu, teks memiliki peran yang sangat penting sebagai sarana dalam beradaptasi dengan sosial. Untuk itu, Kurikulum 2013 yang diusung Badan Pengembangan dan Pembinaan Bahasa dengan skema pembelajaran berbasis teks membawa paradigma baru bagi pendidikan Indonesia. Pembelajaran teks membawa anak menyelesaikan masalah kehidupan nyata dengan berpikir kritis. Begitu pula halnya dalam beradaptasi dengan sosial. Dalam beradaptasi, seseorang harus mengomunikasikan pesan, pikiran, gagasan, dan idenya melalui teks dengan menggunakan bahasa sebagai medianya. Kajian ini menggunakan metode deskriptif, untuk memeroleh gambaran penggunaan teks sebagai sarana adaptasi sosial. Dengan melihat buku pelajaran bahasa Indonesia, baik kelas I, IV, VII, dan $\mathrm{X}$, dapat disimpulkan bahwa setiap teks yang berbeda mempunyai fungsi sosial yang berbeda seiring dengan perbedaan tujuan komunikasi di antara sesama manusia.
\end{abstract}

Kata kunci: teks, pembelajaran teks, adaptasi sosial, bahasa, dan komunikasi.

Gramatika, Volume II, Nomor 2, Juni-Desember 2014 


\section{Pendahuluan}

Dalam Kurikulum 2013, bahasa Indonesia memiliki peran yang sangat penting. Saat ini, bahasa Indonesia dijadikan mata pelajaran penghela dan pembawa pengetahuan (carrier of knowledge). Tentu saja hal inimemosisikan bahasa Indonesia pada tempat yang sangat bermartabat, tidak lagi dilecehkan seperti masa sebelumnya.

Sebagai penghela pengetahuan, bahasa dijadikan wahana untuk mengekspresikan perasaan dan pemikiran secara estetis dan logis. Bahasa, selain dituntut dapat mengekspresikan sesuatu dengan efisien karena ingin menyampaikannya dengan indah sehingga mampu menggugah perasaan penerimanya, juga dituntut efisien dalam menyampaikan gagasan secara objektif dan logis supaya dapat diterima dengan mudah oleh penerimanya. Oleh sebab itu, untuk mengekspresikan dua dimensi diri ini, yaitu perasaan dan pemikiran, bahasa perlu diberikan secara berimbang. Oleh karena itu, pembelajaran bahasa Indonesia disusun dengan berbasis teks, guna menempatkan bahasa Indonesia sebagai wahana untuk mengekspresikan perasaan dan pemikiran.

Untuk memberlakukan Kurikulum 2013, proses pembelajaran bahasa Indonesia haruslah mampu membawa proses pembelajaran lain, seperti IPAdan IPS di sekolah dasar, karena menggunakan pembelajaran tematik. Untuk itu, semua pelajaran bahasa Indonesia, mulai jenjang sekolah dasar (SD) sampai dengan sekolah menengah atas (SMA) dirancang secara utuh berbasis teks. Dengan berbasis teks, siswa menggunakan bahasa tidak hanya sebagai sarana komunikasi, tetapi juga sebagai sarana yang mengembangkan kemampuan berpikir. Dengan demikian, pembelajaran berbasis teks ini perlu segera dipahami oleh pemerhati pengajaran bahasa Indonesia, guru bahasa Indonesia, mahasiswa, dan pihak-pihak yang terkait (Mahsun, "Pembelajaran Bahasa Indonesia Menggunakan Pendekatan Teks”, 2013).

Berkomunikasi merupakan hal mendasar bagi seseorang dalam kehidupan sosial. Rasa ingin tahu manusia sebagai makhluk sosial senantiasa menjadi penyebab manusia ingin selalu berhubungan dengan manusia lainnya. Oleh sebab itu, komunikasi menjadi penting dalam hal ini. Komunikasi dan masyarakat adalah elemen utama dalam kehidupan sosial yang tidak dapat terpisahkan satu dengan yang lainnya. Tanpa adanya komunikasi, tidak mungkin masyarakat bisa terbentuk, dan begitu pula sebaliknya. Tanpa ada masyarakat, maka manusia tidak mungkin dapat mengembangkan komunikasi.

Komunikasi telah menjadi bagian dari kehidupan manusia. Dalam komunikasi terdapat pesan yang hendak disampaikan seseorang kepada orang lain, baik secara individu maupun berkelompok. Agar pesan yang akan disampaikan itu bisa mencapai tujuan, diperlukan teks dengan bahasa sebagai medianya. Oleh sebab itu, teks memiliki peran yang sangat penting sebagai sarana dalam beradaptasi dengan sosial. Tidak ada satu pun aktivitas manusia yang terlepas dari peran dan fungsi teks sebagai bagian dari bahasa.

Setiap teks yang berbeda mempunyai fungsi sosial yang berbeda seiring dengan perbedaan tujuan komunikasi di antara sesama manusia. Ini berarti bahwa dalam menjalani kehidupan, manusia berkomunikasi dengan menggunakan berbagai jenis teks untuk beradaptasi dengan peristiwa sosial yang ada di sekelilingnya. Dengan teks, manusia dapat beradaptasi di bidang sosial, ekonomi, budaya, politik, seni, sastra, kesehatan, dan sebagainya. Lalu, bagaimana penggunaan teks pada pembelajaran bahasa Indonesia, baik di kelas I, IV, VII, dan X dalam pelaksanaan Kurikulum 2013, sehingga menjadi sarana adaptasi sosial? Berangkat dari pertanyaan ini, penulis melakukan penelitian dengan maksud untuk melihat bagaimana penggunaan teks tersebut pada buku tematik kelas I dan IV, serta buku bahasa Indonesia kelas VII (Bahasa Indonesia Wahana Pengetahuan) dan kelas X (Bahasa Indonesia Ekspresi Diri dan Akademik) sebagai sarana adaptasi sosial.

Menyoal pembelajaran bahasa berbasis teks tersebut telah dilakukan oleh beberapa orang, antara lain Main Sufanti dan Maryanto. Main Sufanti (Magister Pengkajian Bahasa Pascasarjana Univesitas Muhammadiyah Surakarta) dalam tulisannya berjudul "Pembelajaran Bahasa Indonesia Berbasis Teks: Belajar dari Ohio Amerika Serikat" menyatakan bahwa apa yang dicanangkan dalam Kurikulum 2013 itu bukan sesuatu yang baru. Dengan membandingkan pembelajaran bahasa Indonesia pada Kuri- 
kulum 2013 dengan pembelajaran di Liberty Middle School, Main Sufanti mengusulkan beberapa hal terkait implementasi pembelajran bahasa berbasis teks tersebut. Sementara itu, Maryanto (seorang pemerhati politik bahasa yang menjadi anggota tim penyusun buku Kurikulum 2013) dalam artikelnya yang berjudul "Kurikulum 'Struktur Teks"' (Kompas, 3 April 2013) membahas berbagai perubahan yang terjadi pada pembelajaran bahasa Indonesia pada satuan pendidikan di Indonesia.

Berbeda dengan kajian tentang pembelajaran teks yang telah dibahas oleh beberapa orang tersebut, dalam kajian ini dibahas tentang penggunaan teks sebagai sarana adaptasi sosial, baik yang dipelajari di kelas I, IV, VII, maupun X. Dengan menggunakan metode deskriptif, setiap teks yang muncul dalam pembelajaran bahasa Indonesia akan memperlihatkan fungsinya sebagai adaptasi sosial.

\section{Hasil dan Pembahasan}

\subsection{Bahasa dan Komunikasi}

Bahasa adalah satu faktor mendasar yang membedakan manusia dengan makhluk lainnya. Bahasa memungkinkan individu dapat hidup bersama dengan orang lain, membantu memecahkan masalah, dan memosisikan manusia sebagai makhluk yang berbudaya.

Badudu (1989) dalam Metode Pengembangan Bahasa (Dieni, 2009:1.11) mendefinisikan bahasa sebagai alat penghubung atau komunikasi antara anggota masyarakat yang terdiri atas individu dalam menyatakan pikiran, perasaan, dan keinginannya. Nurbiana juga mengutip pernyataan Broemly bahwa bahasa merupakan sistem simbol yang teratur dalam bentuk visual maupun verbal untuk mentransfer berbagai ide maupun informasi. Individu dapat memanipulasi berbagai simbol tersebut dengan berbagai cara sesuai dengan kemampuan berpikirnya.

Dikaitkan dengan bahasa, komunikasi tidak terbatas pada bahasa verbal saja. Beberapa ahli berpendapat ketika beberapa orang berada pada satu tempat yang sama, pasti terjadi komunikasi. Sekalipun mereka tidak berbicara, tetapi terjadi bentuk komunikasi yang lain. Hal tersebut dapat diekspre- sikan melalui bahasa tubuh, ekspresi wajah, dan suara nonlinguistik, seperti menggumam atau menggerutu. Dengan demikian komunikasi merupakan pemindahan suatu arti melalui suara, tanda, bahasa tubuh, dan simbol. Sementara itu, bahasa merupakan sistem simbol yang teratur untuk mentaransfer arti tersebut. Bahasa dapat dikatakan sebagai sistem simbol khusus yang dipahami dan digunakan sekelompok individu untuk mengomunikasikan berbagai ide dan informasi.

Broemly (dalam Metode Pengembengan $\mathrm{Ba}$ hasa, 2009) menyebutkan empat bentuk bahasa, yaitu menyimak, berbicara, membaca, dan menulis. Bahasa ada yang bersifat reseptif (menerima) dan juga ekspresif(mengungkapkan). Mendengarkan (menyimak) dan membaca suatu informasi bersifat reseptif, sedangkan berbicara dan menuliskan informasi untuk dikomunikasikan kepada orang lain bersifat ekspresif. Selain itu, bahasa juga memiliki lima fungsi. Pertama, bahasa menjelaskan keinginan dan kebutuhan individu. Kedua, bahasa mengubah dan mengontrol perilaku. Ketiga, bahasa membantu perkembangan kognitif. Keempat, bahasa membantu mempererat interaksi dengan orang lain. Serta yang kelima, bahasa mengekspresikan keunikan individu.

Akibat adanya dorongan rasa ingin tahu yang ada dalam diri tiap manusia,komunikasi menjadi sangat penting. Sebagaimakhluk sosial, manusia senantiasa ingin berhubungan dengan manusia lainnya. Berkomunikasi adalah hal mendasar bagi seseorang dalam hidup bermasyarakat. Wilbur Schramm (dalam Cangara, 2010: 1-2) menyebutkan bahwa komunikasi dan masyarakat adalah dua kata kembar yang tidak dapat dipisahkan satu sama lainnya. Sebab, tanpa komunikasi tidak mungkin masyarakat bisa terbentuk, sebaliknya tanpa masyarakat maka manusia tidak mungkin dapat mengembangkan komunikasi.

Komunikasi telah menjadi bagian dari kehidupan manusia. Dalam sebuah komunikasi, setidaknya terdapat beberapa unsur yang diperlukan, seperti sumber (pembicaraan), pesan (message), media (channel, saluran), dan penerima (receiver, audience) (Widjaja, 2010: 1).Semua peristiwa komunikasi akan melibatkan sumber sebagai pembuat atau pengirim informasi. Dalam komunikasi antarmanusia, sumber 
bisa terdiri atas satu orang atau pun berkelompok. Sumber sering pula disebut sebagai pengirim atau komunikator. Sementara itu, pesan dalam proses komunikasi adalah sesuatu yang disampaikan pengirim kepada penerima. Pesan dapat disampaikan secara tatap muka atau melalui media komunikasi. Media yang dimaksud di sini adalah alat yang digunakan untuk memindahkan pesan dari sumber kepada penerima. Penerima merupakan pihak yang menjadi sasaran pesan yang dikirim oleh sumber. Penerima bisa terdiri dari satu orang atau lebih.

Bahasa, dapat dikatakan sebagai media dalam berkomunikasi. Bahasa mencakup cara untuk berkomunikasi yang digunakan untuk menyatakan pikiran dan perasaan melalui lambang atau simbol seperti lisan, tulisan, isyarat, bilangan, lukisan, atau apa saja yang digunakan untuk mengungkapkan sesuatu. Bahasa sebagai fungsi dari komunikasi memungkinkan dua individu atau lebih mengekspresikan berbagai ide, arti, perasaan, dan pengalaman. Meskipun bahasa bukan merupakan syarat utama dalam kemampuan berpikir yang luas, tetapi bahasa membantu kemampuan berpikir, karena kemampuan berbahasa dan berpikir ini berkembang secara bersamaan.

\subsection{Komunikasi sebagai Bentuk Adaptasi Sosial}

Dalam kehidupan, manusia selain sebagai makhluk yang berpikir (homo sapiens) juga merupakan makhluk bermasyarakat (homo socius). Artinya, dalam keseharian, tidak mungkin seorang manusia hidup tanpa orang lain. Seorang manusia yang individual merupakan organisme tunggal. Tanpa bantuan orang lain, individu tersebut tidak akan bisa hidup sempurna. Oleh sebab itulah seseorang membutuhkan orang lain dalam menyempurnakan hidupnya.

Akan tetapi, dalam bermasyarakat, seorang individu tidak serta-merta mengenal individu atau kelompok masyarakat lainnya, padahal mereka harus melakukan interaksi agar terpenuhi kebutuhan dan keinginan masing-masing. Sebagai makhluk sosial, seorang individu atau kelompok harus berusaha menciptakan keserasian dan keselarasan dengan ling- kungannya. Untuk itu, dibutuhkan kemampuan beradaptasi.

Adaptasi merupakan bentuk penyesuaian yang dilakukan makhluk hidup agar bisa bertahan hidup dalam lingkungannya, terutama pada lingkungan yang baru. Kemampuan makhluk hidup untuk menyesuaikan diri terhadap lingkungannya ini dapat membantunya mengatasi tekanan yang dialaminya. Adaptasi ini kemudian akan memengaruhi berbagai aspek kehidupan.

Dalam proses kehidupan manusia sebagai anggota masyarakat, individu tidak dapat melakukan hal yang diinginkannya begitu saja, karena individu tersebut mempunyai lingkungan di luar dirinya, baik lingkungan fisik maupun lingkungan sosial. Lingkungannya ini memiliki aturan dan norma yang dapat membatasi polah individu tersebut. Untuk itu, tiap individu harus mampu beradaptasi terhadap lingkungannya, yang dikenal dengan istilah adaptasi sosial.

Dalam Kamus Besar Bahasa Indonesia (KBBI, 2011: 8), adaptasi sosial merupakan perubahan yang mengakibatkan seseorang di suatu kelompok sosial dapat hidup dan berfungsi lebih baik di lingkungannya. Dalamberadaptasi terhadap lingkungan sosial, terjadi penyesuaian diri individu terhadap lingkungan, dan juga sebaliknya, terjadi perubahan lingkungan sesuai dengan keadaan individu. Pada hakikatnya, adaptasimerupakan suatu proses untuk memenuhi syarat dasar dalam melangsungkan kehidupan (http://www. psychologymania.com/2012/11/adaptasi-sosial.html).

Untuk dapat menyesuaikan diri terhadap lingkungan, tiap individu melakukan komunikasi. Dalam berkomunikasi ini, salah satu alat yang paling sering digunakan adalah bahasa, baik bahasa lisan maupun tulisan. Kemampuan berbahasa diperoleh dan dipelajari seseorang secara alamiah untuk beradaptasi dengan lingkungannya. Bahasa dijadikan alat untuk bersosialisasi dengan merespons orang lain.

Dalam berkomunikasi tidak tertutup kemungkinan terjadi gangguan. Gangguan komunikasi dapat terjadi pada semua elemen atau unsur yang mendukungnya. Menurut Shannon dan Weaver (dalam Cangara, 2010: 153) gangguan komunikasi terjadi jika terdapat intervensi yang mengganggu salah satu elemen komunikasi, sehingga proses komunikasi tidak 
dapat berlangsung secara efektif. Gangguan komunikasi menurut Cangara (2010) salah satunya adalah gangguan semantik. Blake (dalam Cangara, 2010: 154) berpendapat bahwa gangguan semantik merupakan gangguan komunikasi yang disebabkan karena kesalahan pada bahasa yang digunakan. Gangguan semantik ini sering terjadi karena (1) kata-kata yang digunakan terlalu banyak memakai jargon bahasa asing sehingga sulit dimengerti oleh khalayak tertentu, (2) bahasa yang digunakan pembicara berbeda dengan bahasa yang digunakan oleh penerima, (3) struktur bahasa yang digunakan tidak sebagaimana mestinya sehingga membingungkan penerima, dan (4) latar belakang budaya yang menyebabkan salah persepsi terhadap simbol-simbol bahasa yang digunakan.

Oleh karena itu, agar pesan yang hendak disampaikan oleh sumber kepada penerima tidak mengalami gangguan perlu adanya strategi komunikasi. Strategi komunikasi ini harus mampu menunjukkan bagaimana melakukan operasionalnya secara praktis. Artinya bahwa pendekatan yang dilakukan pada tiap komunikasi akan bergantung pada situasi dan kondisi yang ada (Onong Uchjana Effendy, 2005: 32).

\subsection{Menggunakan Teks Sebagai Sarana Adaptasi Sosial}

\subsubsection{Pembelajaran Teks dan Adaptasi Sosial}

Dalam Kurikulum 2013, bahasa Indonesia memiliki peran yang sangat penting. Saat ini, bahasa Indonesia dijadikan mata pelajaran penghela dan pembawa pengetahuan (carrier of knowledge). Tentu saja hal ini memosisikan bahasa Indonesia pada tempat yang sangat bermartabat, tidak lagi dilecehkan seperti masa sebelumnya.

Sebagai penghela pengetahuan, bahasa dijadikan wahana untuk menerima informasi serta mengekspresikan perasaan dan pemikiran secara estetis dan logis. Menerima dan mengekspresikan bahasa dapat dilakukan dengan berbagai cara. Keterampilan menyimak dan membaca merupakan keterampilan bahasa reseptif karena dalam keterampilan ini makna bahasa diperoleh dan diproses melalui simbol visual dan verbal. Dengan demikian, menyimak dan membaca juga merupakan proses pemahaman (compre- hending proses). Sementara itu, keterampilan berbicara dan menulis merupakan keterampilan bahasa ekspresif yang melibatkan pemindahana arti melalui simbol visual dan verbal yang diproses dan diekspresikan seseorang. Ketika seseorang berbicara dan menulis, terjadi penyusunan bahasa dan pengonsepan arti. Dengan demikian, berbicara dan menulis merupakan proses penyusunan (composing process). Mengembangkan keterampilan pemahaman dan penyusunan ini merupakan dasar bagi kegiatan belajar siswa secara umum (Dieni, dkk., Metode Pengembangan Bahasa, 2009).

Untuk dapat mengembangkan keterampilan pemahaman dan penyusunan tersebut, diperlukan teks dengan bahasa sebagai medianya, sebab semua bahasa yang mengambil bagian tertentu dalam konteks situasi dapat dinamakan teks. Teks itu berkaitan dengan segala hal yang dilakukan, dimaknai, dan dikatakan oleh masyarakat dalam situasi yang nyata. Dengan demikian, teks selalu dimaknai secara dinamis (Halliday, 1978: 109).

Teks, yang merupakan satuan bahasa mengandung makna, pikiran, dan gagasan yang lengkap secara kontekstual, tidak selalu berwujud bahasa tulis. Teks ini dapat berwujud baik tulis maupun lisan, bahkan teks dapat berwujud perpaduan antara teks lisan atau tulis dan gambar/animasi/film. Secara konkret, teks merupakan sebuah objek, tetapi secara abstrak, teks merupakan satuan bahasa di dalam wilayah bahasa sebagai sistem, serta mempunyai tata organisasi yang kohesif.

Untuk mengomunikasikan makna, pikiran, atau gagasan tersebut terhadap orang lain, digunakan teks dengan bahasa sebagai medianya. Bahasa tidaklah berisi kata atau kalimat, tetapi bahasa itu berisi teks, yakni pertukaran makna (exchange or meaning) dalam konteks interpersonal. Mengkaji bahasa hakikatnya mengkaji teks yang selalu melibatkan konteks. Dalam bukunya yang berjudul Studi $\mathrm{Ba}$ hasa Kritis: Menguak Bahasa Membongkar Kuasa, Anang Santoso (2012:84) mengutip pernyataan Halliday yang selalu menegaskan bahwa bahasa adalah produk proses sosial. Seseorang yang belajar bahasa berarti dalam waktu yang sama belajar sesuatu yang lain pula melalui bahasa tersebut, yakni 
membangun gambaran realitas di sekitar dan di dalamnya. Menurutnya, bahasa selalu berhubungan erat dengan aspek sosial. Dalam proses sosial ini, konstruk realitas tidak dapat dipisahkan dari konstruk sistem semantis tempat realitas itu dikodekan. Dalam sebuah interaksi, setiap partisipan akan selalu menafsirkan teks yang ada. Dengan demikian, akan selalu ada makna ganda, dan tidak ada makna yang tunggal. Oleh sebab itu, agar tidak terjadi kesalahpahaman penafsiran, dibutuhkan komunikasiyang intensif.

Agar seseorang tidak tersingkir dari kehidupan masyarakatnya, ia harus beradaptasi terhadap kehidupan sosialnya. Adaptasi sosial, yang merupakan kecenderungan makhluk hidup menyesuaikan diri dengan lingkungannya untuk dapat tetap hidup dengan baik, harus dilakukan oleh individu yang hidup bermasyarakat. Pada hakikatnya, adaptasi itu sendiri merupakan suatu proses untuk memenuhi syarat dasar untuk tetap dapat melangsungkan kehidupan. Dalam proses kehidupan manusia sebagai anggota masyarakat, individu tidak dapat begitu saja untuk melakukan tindakan yang dianggap sesuai dengan dirinya, karena individu tersebut mempunyai lingkungan di luar dirinya, baik lingkungan fisik maupun lingkungan sosial. Seseorang harus mampu menyesuaikan diri dengan tatanan kemasyarakatan yang dijalaninya. Untuk itu, diperlukan adanya komunikasi satu dengan yang lainnya.

Pada saat individu beradaptasi terhadap lingkungan sosial tertentu, individu tersebut akan memilih teks yang tepat dan sesuai dengan konteks yang dihadapi. Dalam hal ini, bahasa digunakan sebagai alat untuk menyatukan berbagai ragam individu yang memiliki sifat dan karakter yang berbeda. Teks dalam bahasa yang digunakan oleh individu tersebut, memungkinkannya untuk merasa terikat dengan kelompok sosial yang dimasukinya.

\subsubsection{Pembelajaran Bahasa Berbasis Teks dalam Kurikulum 2013}

Pembelajaran bahasa berbasis teks kerap pula disebut sebagai pembelajaran bahasa berbasis genre. Genre merupakan sebuah proses interaksi sosial dan budaya yang melatarbelakangi terciptanya teks dengan berbagai jenis yang berbeda. Proses sosial ini berorientasi pada tujuan yang hendak dicapai secara bertahap. Dalam hal ini, kata "sosial” berfungsi memperlihatkan bahwa genre digunakan seseorang untuk berkomunikasi dengan orang lain. Komunikasi yang dilakukan tersebut memilikitujuan. Untuk dapat mencapai tujuan itu, dibutuhkan beberapa tahapan komunikasi. Oleh sebab itulah genre dikatakan sebagai sebuah proses sosial yang melalui beberapa tahapan mencapai sebuah tujuan yang diharapkan.

Secara garis besar, pembelajaran dan pengajaran bahasa di dunia didasari atas tiga kelompok teori kebahasaan yang dicetuskan Richards dan Rodgers, yaitu teori struktural (structural view), teori fungsional (functional view), dan teori interaksionis (interactionist view).

Pada teori struktural, bahasa dikatakan sebagai suatu sistem tentang unsur struktural yang saling berkaitan untuk menyatakan makna. Dalam pandangan ini, pembelajaran bahasa dilihat sebagai penguasaan unsur struktural yang mencakupi fonologi, gramatikal, leksikal, dan sebagainya. Pada teori fungsional, bahasa dipandang sebagai alat untuk mengungkapkan makna yang sesuai dengan fungsi yang dikehendaki. Menurut pandangan yang lebih menekankan unsur semantik dan komunikatif ini, pembelajaran bahasa menitikberatkan kandungan bahasa yang lebih didasarkan pada fungsi dan makna. Sementara itu, pada teori interaksionis, bahasa digunakan sebagai alat untuk merealisasikan hubungan antarmanusia. Oleh sebab itu, bahasa dilihat sebagai perwujudan usaha yang dilakukan oleh penggunanya untuk melangsungkan interaksi sosial.

Akan tetapi, Tri Wiratno (dalam Sosialisasi Pembelajaran Bahasa Indonesia dalam Implementasi Kurikulum 2013 yang ditaja oleh Badan Bahasa, 2013) menyebutkan bahwa sejak akhir tahun 1980an telah diterapkan sebuah teori yang diyakini secara umum sebagai induk teori, yaitu teori linguistik sistemik fungsional atau LSF (Halliday, 1985; Halliday \& Matthiessen, 2004) dan teori genre (Martin, 1985; Martin, 1992). Pada teori ini, bahasa selalu digunakan dalam wujud teks yang dilingkupi oleh konteks situasi dan konteks budaya. Mengajarkan bahasa berarti mengajarkan cara menggunakan bentuk bahasa yang mengungkapkan diri sendiri, dunia sekitar, 
pengalaman, serta nilai sosial dan budaya. Dalam penerapan teori ini, digunakan pendekatan komunikatif (communicative approach) yang berpandangan bahwa dalam berkomunikasi, agar sesuai dengan fungsi yang diemban oleh bahasa, dibutuhkan seperangkat pengetahuan dan kemampuan. Untuk mengetahui fungsi bahasa yang digunakan, lahirlah pendekatan mengajar berbasis teks (genre based approach).

Berdasarkan pemikiran inilah mata pelajaran bahasa Indonesia di sekolah pada Kurikulum 2013 menggunakan pembelajaran bahasa berbasis teks yang sering pula disebut sebagai pembelajaran berbasis genre. Pembelajaran bahasa Indonesia berbasis genre atau berbasis teks ini dilaksanakan dengan menerapkan beberapa prinsip berikut ini. Pertama, bahasa hendaknya dipandang sebagai teks, bukan semata-mata kumpulan kata atau kaidah kebahasaan. Kedua, penggunaan bahasa merupakan proses pemilihan bentuk kebahasaan untuk mengungkapkan makna. Ketiga, bahasa bersifat fungsional, yaitu penggunaan bahasa tidak pernah bisa dilepaskan dari konteks, karena bentuk bahasa yang digunakan itu mencerminkan ide, sikap, nilai, dan ideologi penggunanya. Keempat, bahasa merupakan sarana pembentukan kemampuan berpikir manusia, dan cara berpikir itu direalisasikan melalui struktur teks.

Teks inimemiliki dua unsur utama, yaitu konteks situasi dan konteks budaya. Konteks situasi berkenaan dengan penggunaan bahasa yang melatarbelakangi lahirnya teks. Sementara itu, konteks budaya disebut juga konteks sosial, merupakan masyarakat tutur bahasa yang menjadi tempat berbagaijenis teks tersebut diproduksi. Pada konteks situasi yang berkenaan dengan penggunaan bahasa lahirnya sebuah teks terdapat suatu hal yang hendak disampaikan, yaitu pesan, pikiran, gagasan, maupun ide. Dalam teks tersebut juga terdapat sasaran atau partisipan yang dituju oleh pesan, pikiran, gagasan, dan ide tersebut. Selain itu, dalam teks tersebut juga terdapat format bahasa yang digunakan untuk menyampaikan atau mengemas pesan, pikiran, gagasan, atau ide yang dimaksud, sehingga terbentuklah berbagai jenis teks. Teks tersebut antara lain teks deskripsi, laporan, pro-

Gramatika, Volume II, Nomor 2, Juni-Desember 2014 sedur, eksplanasi, eksposisi, diskusi, naratif, cerita ulang, anekdot, dan lain-lain.

Sebuah teks memiliki struktur. Struktur teks membentuk struktur berpikir, sehingga di setiap penguasaan jenis teks tertentu, siswa akan memiliki kemampuan berpikir sesuai dengan struktur teks yang dikuasainya. Dengan berbagai macam teks yang dikuasainya, siswa akan mampu menguasai berbagai struktur berpikir. Dengan kata lain, satu topik tertentu dapat disajikan ke dalam jenis teks yang berbeda dan tentunya dengan struktur berpikir yang berbeda pula. Hanya dengan cara itu, siswa kemudian dapat mengonstruksi ilmu pengetahuannya melalui kemampuan mengobservasi, mempertanyakan, mengasosiasikan, menganalisis, dan menyajikan hasil analisis secara memadai (Prawacana, Bahasa Indonesia Ekspresi Diri dan Akademik, 2013).

Pada pengajaran dan pembelajaran berbasis teks ini, terdapat empat tahap yang harus ditempuh sebagai berikut: (1) tahap pembangunan konteks; (2) tahap pemodelan teks; (3) tahap pembangunan teks secara bersama-sama; dan (4) tahap pembangunan teks secara mandiri. Keempat tahap itu berlangsung secara siklus. Guru dapat memulai kegiatan belajar-mengajar dari tahap manapun, meskipun pada umumnya semua tahap itu ditempuh secara urut. Selain itu, apabila kegiatan belajar-mengajar mengalami kesulitan pada tahap tertentu, misalnya pembuatan teks secara bersama, guru boleh mengarahkan siswa untuk kembali kepada tahap pemodelan.

Setiap pembelajaran pada buku Bahasa Indonesia untuk siswa yang diterbitkan oleh Kementerian Pendidikan dan Kebudayaan terdapat tiga kegiatan belajar. Kegiatan Belajar 1 berkenaan dengan tahap pembangunan konteks, yang kemudian dilanjutkan dengan pemodelan teks. Pembangunan konteks dimaksudkan sebagai langkah awal bagi guru dan siswa untuk mengarahkan pemikiran ke dalam pokok persoalan yang akan dibahas pada setiap pelajaran. Sementara itu, tahap pemodelan teks merupakan tahap yang berisi tentang pembahasan teks yang diberikan sebagai model pembelajaran. Pembahasan diarahkan kepada struktur pembangun teks dan semua aspek kebahasaan yang membentuk teks itu secara keseluruhan. Tahap pembangunan teks secara 
bersama-sama dilaksanakan pada Kegiatan Belajar 2. Pada tahap ini, siswa secara bersama-sama dan guru sebagai fasilitator menyusun kembali teks seperti yang ditunjukkan pada teks model. Tugas yang diberikan berupa struktur pembangun teks itu sendiri dan semua aspek kebahasaan yang sesuai dengan ciri yang dituntut pada jenis teks yang dimaksud. Setelah itu, dilanjutkan dengan Kegiatan Belajar 3. Pada kegiatan ini merupakan kegiatan belajar mandiri. Pada tahap ini siswa diharapkan dapat mengaktualisasikan diri dengan menggunakan teks sesuai dengan jenis dan ciri seperti yang ditunjukkan pada teks model (Prawacana, Bahasa Indonesia Ekspresi Diri dan Akademik, 2013).

Seorang siswa dapat memahami dan mengingat suatu informasi jika siswa tersebut mendapat kesempatan untuk membicarakannya, menuliskannya, menggambarkannya, dan memanipulasinya. Siswa belajar membaca dan menyimak jika ia mendapat kesempatan untuk mengekspresikan pemahaman mereka dengan membicarakannya maupun menuliskannya untuk diri sendiri maupun ditujukan untuk orang lain. Belajar akan terjadi jika ada diskusi antara guru dan siswa, sesama siswa, siswa dan buku, serta siswa dan lingkungannya. Bahasa dan belajar tidak dapat dipisahkan. Kemampuan menggunakan bahasa secara efektif sangat berperan penting terhadap kemampuan belajarnya.

Empat bentuk bahasa yang disebutkan Broemly di muka, yaitu menyimak, berbicara, membaca, dan menulis dapat terlihat jelas dalam pembelajaran bahasa Indonesia pada Kurikulum 2013 ini. Melalui empat tahapan pembelajaran berbasis teks ini, dengan mengacu pada kompetensi inti dan kompetensi dasar yang telah ditetapkan, siswa menjadi tahu struktur dan fungsi sosial tiap teks yang ada. Pembelajaran dalam Kurikulum 2013 ini mengangkat tiga objek pembelajaran, yaitu fenomena alam, sosial, dan budaya. Ketiga komponen dipadukan dengan menggunakan pendekatan tematik-integratif. Dengan menguasai ketiga fenomena ini, siswa tidak akan kesulitan dalam beradaptasi dengan lingkungannya. Jika siswa menggunakan teks yang tepat dan sesuai, melalui pendekatan saintifik, yaitu dengan cara mengamati (observing), menanya (questioning), menalar (associating), mencoba (experimenting), dan mengomunikasikan (networking), siswa akan mampu dalam masyarakat yang mengglobal.

\section{Penutup}

Penggunaan bahasa seseorang akan memengaruhi perkembangan sosial, emosional, fisik, dan kognitif. Hal ini menunjukkan bahwa kemampuan seseorang terhadap berbagai bidang terlihat pada kemampuan berbahasanya. Oleh sebab itu, bahasa dijadikan penghela ilmu pengetahuan (carrier of knowledge) dalam Kurikulum 2013. Diyakini bahwa keberhasilan anak dalam berbagai area, seperti ilmu pengetahuan alam, ilmu pengetahuan sosial, atau matematika tergantung pada kemampuan anak untuk memahami dan menyusun bahasa. Fenomena bahasa sebagai ilmu dapat menjadi objek ilmu linguistik, yakni ilmu tentang bahasa, termasuk fonologi, morfologi, sintaksis, semantik, dan lain-lain. Sebagai sarana komunikasi, bahasa dipelajari dalam bentuk keterampilan menyimak, berbicara, menulis, dan membaca segala aspek kehidupan yang dituangkan dalam suatu teks atau bacaan.

Bahasa itu adalah sarana berpikir. Artinya, struktur bahasa seseorang memengaruhi cara berpikir atau cara manusia memandang dunia atau memandang makna kehidupan yang terekam dalam struktur bahasanya. Bahasa adalah pikiran atau konsep yang menghasilkan teks atau genre.Melalui bahasa, akan tercipta insan yang memiliki kemampuan berpikir sistematis, terkontrol, empirik, dan kritis. Hal itu dapat dicapai melalui pendekatan saintifik, yaitu dengan cara mengamati (observing), menanya (questioning), menalar (associating), mencoba (experimenting), dan mengomunikasikan(networking).

Setiap teks yang berbeda mempunyai struktur dan fungsi sosial yang berbeda. Dengan mempelajari setiap teks yang disajikan pada buku tematik kelas I dan IV, serta buku bahasa Indonesia kelas VII ( $\mathrm{Ba}$ hasa Indonesia Wahana Pengetahuan) dan kelas X (Bahasa Indonesia Ekspresi Diri dan Akademik) dapat diketahuibahwa untuk menyatakan tema tertentu dapat menggunakan teks tertentu. Selain itu, 
beberapa jenis teks yang berbeda dapat digunakan untuk menyatakan tema yang sama atau jenis teks yang sama dapat pula digunakan untuk menyatakan tema yang berbeda. Setiap teks dengan jenis yang sama mengandung struktur teks dan fungsi sosial yang sama. Begitu pula sebaliknya, jenis teks yang berbeda mengandung struktur dan fungsi sosial yang berbeda pula.

Berangkat dari kenyataan tersebut, siswa akan menjadi kritis dan menggunakan alur berpikirnya sesuai dengan konteks yang ada. Dengan menguasai struktur dan fungsi sosial sebuah teks, siswa mampu beradaptasi terhadap lingkungan sosialnya. Maka, melalui pembelajaran bahasa berbasis teks, siswa diyakini akan mampu menghadapi tantangan masa depan, meski arus globalisasi terus saja menghampiri.

\section{Daftar Pustaka}

Cangara, Hafied. 2010. Pengantar Ilmu Komunikasi. Jakarta: PT Raja Grasindo Persada.

Departemen Pendidikan Nasional. 2011. Kamus Besar Bahasa Indonesia. Jakarta: PT Gramedia Pustaka Utama.

Dhieni, Nurbiana et al. 2009. Metode Pengembangan Bahasa. Jakarta: Universitas Terbuka.

Effendy, Onong Uchjana. 2005. Ilmu Komunikasi: Teori dan Praktek. Bandung: PT Remaja Rosdakarya.

Halliday, M.A.K. 1978. Language as Sosial Semiotic: The Social Interpretation of Language and Meaning. London: Edward Arnold.
Indonesia. 2013. Bahasa Indonesia Ekspresi Diri dan Akademik. Jakarta: Kementerian Pedidikan dan Kebudayaan.

Mahsun. 2013. "Pembelajaran Bahasa Indonesia Menggunakan Pendekatan Teks". (Kompas $E d u, 27$ Februari 2013, diakses 8 April 2013).

Maryanto. 2013. "Kurikulum 'Struktur Teks"”. Kompas, 3 April 2013.

Psychologymania, Pusat Informasi Psikologi. 2012. "Adaptasi Sosial". (http://www.psychologymania. com/2012/11/adaptasi-sosial.html, diakses 6 Maret 2014).

Santoso, Anang. 2012. Studi Bahasa Kritis: Menguak Bahasa Membongkar Kuasa. Bandung: Mandar Maju.

Sufanti, Main. 2013. 'Pembelajaran Bahasa Indonesia Berbasis Teks: Belajar dari Ohio Amerika Serikat". (publikasiilmiah.ums.ac.id, diakses 6 Maret 2014).

Widjaja, H.A.W. 2010. Komunikasi:Komunikasi dan Hubungan Masyarakat. Jakarta: Bumi Aksara.

Wiratno, Tri. 2013. 'Pembelajaran BahasaBerbasis Teks dan Jenis-Jenis Teks". Makalah pada Sosialisasi Pembelajaran Bahasa Indonesia dalam Implementasi Kurikulum 2013. Jakarta: Badan Pengembangan dan Pembinaan Bahasa, Kementerian Pendidikan dan Kebudayaan. 